\title{
THE INFLUENCE OF AGE ON RED CELL DIAMETER
}

\author{
BY \\ A. I. SPRIGGS AND R. A. SLADDEN \\ From the United Oxford Hospitals
}

(RECEIVED FOR PUBLICATION APRIL 24, 1957)

During the examination of stained blood films from hospital patients, the impression was gained that the red cells tended to be larger in old age than in young or middle life. To investigate this possibility, halometer readings were made on blood films from patients of different ages, and enough evidence was collected to show that there were statistically significant differences between various age groups.

There is very little information about the effect of age on mean red cell diameter (M.C.D.). Saragea (1922) measured the red cell diameters of people in all the decades of age up to 90 , but since only one person was examined for each decade the results were not of much value. Price-Jones (1929) did not demonstrate any significant difference with age. Among 100 normal persons for whom he calculated M.C.D.s, all but five were below the age of 60 , and all but 10 were below the age of 50. The mean reading for all the 10 persons aged over 50 was $7.137 \mu$, which is less than the mean for the whole series $(7.202 \mu)$.

Olbrich (1947) recorded a number of haematological values in old people, and made Price-Jones curves of blood films from 23 men and 26 women over the age of 64 . He compared the figures with those of 10 healthy young persons aged 20-30. The mean of the M.C.D.s for the older age group was $7.6 \mu$ (S.D. $0.187 \mu$, range 7.1-8.0 $\mu$ ), and that for the younger age group was $7.03 \mu$ (S.D. $0.1611 \mu$, range $6.84-7.33 \mu$ ). No significant sex difference was found. Although Olbrich's figures suggest a marked increase of diameter in the elderly, the numbers were too small to show the trend in different decades.

\section{Material and Methods}

Dry, unstained blood films were obtained by finger prick from 25 males and 25 females in each decade of age from the first to the ninth. In the first decade, children below the age of 1 were excluded on account of the well-known macrocytosis of infancy.
The subjects were in-patients and out-patients of the United Oxford Hospitals and the Nuffield Orthopaedic Centre, and, in the second and third decade, some healthy doctors, nurses, and laboratory technicians were included. Most of the older persons were in-patients or out-patients of the Cowley Road Hospital, Oxford.

No selection was exercised except that persons known to be severely anaemic or suffering from blood diseases were excluded. Bone marrow was examined in cases with an M.C.D. of $8 \mu$ or over, and those cases in which it was abnormal were excluded. One reading was taken from each film, using a Waterfield monochromatic halometer. All readings were made by the same observer (A. I. S.), who did not know the source of the film at the time it was read.

\section{Results}

The means of the M.C.D. readings for males and females in each decade are given in Table $I$.

TABLE I

MEANS OF HALOMETER READINGS (IN MICRONS) FOR DIFFERENT SEXES AND AGE GROUPS

\begin{tabular}{|c|c|c|c|c|c|c|c|c|}
\hline \multicolumn{7}{|c|}{ Age } & \multirow[b]{2}{*}{$\begin{array}{l}\text { Male } \\
6.936 \\
6.968 \\
6.984 \\
6.968 \\
7 \cdot 188 \\
7 \cdot 200 \\
7 \cdot 268 \\
7 \cdot 380 \\
7 \cdot 348\end{array}$} & \multirow[b]{2}{*}{$\begin{array}{c}\text { Female } \\
\mathbf{7} \cdot 084 \\
7 \cdot 132 \\
7 \cdot 120 \\
7 \cdot 076 \\
7 \cdot 212 \\
7 \cdot 112 \\
7 \cdot 264 \\
7 \cdot 348 \\
7 \cdot 436\end{array}$} \\
\hline $\begin{array}{r}1-9 \\
10-19 \\
20-29 \\
30-39 \\
40-49 \\
50-59 \\
60-69 \\
70-79 \\
80-89\end{array}$ & $\begin{array}{l}\ldots \\
\cdots \\
\cdots \\
\ldots \\
\cdots \\
\cdots \\
\cdots\end{array}$ & $\begin{array}{l}\ldots \\
\ldots \\
\ldots \\
\ldots \\
\ldots \\
\ldots \\
\ldots\end{array}$ & $\begin{array}{l}\cdots \\
\cdots \\
\ldots \\
\cdots \\
\cdots \\
\cdots \\
\cdots\end{array}$ & $\begin{array}{l}\cdots \\
\cdots \\
\cdots \\
\cdots \\
\cdots \\
\cdots \\
\cdots\end{array}$ & $\begin{array}{l}\cdots \\
\cdots \\
\cdots \\
\cdots \\
\cdots \\
\cdots \\
\cdots\end{array}$ & $\begin{array}{l}\ldots \\
\ldots \\
\ldots \\
\ldots \\
\ldots \\
\ldots \\
\ldots\end{array}$ & & \\
\hline
\end{tabular}

Up to and including the fourth decade (ages 3039) there is no apparent change with age, although the curve for females lies consistently above that for males. The mean for the four decades is $7.03 \mu$. From the fourth decade onwards there is a steady rise in the means, with a regression coefficient of $0.06 \mu$ for each decade.

Table II and Fig. 1 show three distribution curves constructed from the three age groups 1-29, $30-59$, and 60-89. In each of these groups there is a wide scatter, the standard deviations being $0.28,0.28$, and $0.27 \mu$ respectively ; but it will be 
TABLE II

NUMBERS OF CASES FALLING IN THREE AGE GROUPS, CLASSIFIED ACCORDING TO M.C.D. IN MICRONS

\begin{tabular}{|c|c|c|c|}
\hline \multicolumn{2}{|c|}{$\begin{array}{c}\text { No. Persons Aged } \\
1-29\end{array}$} & $\begin{array}{c}\text { No. Persons Aged } \\
30-59\end{array}$ & $\begin{array}{c}\text { No. Persons Aged } \\
60-89\end{array}$ \\
\hline \multirow{9}{*}{ 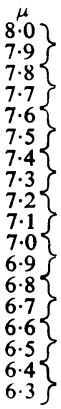 } & 2 & 1 & 5 \\
\hline & 0 & 3 & 11 \\
\hline & 3 & 14 & 39 \\
\hline & 30 & 37 & 35 \\
\hline & 43 & 33 & 36 \\
\hline & 30 & 34 & 19 \\
\hline & 27 & 22 & 5 \\
\hline & 15 & 6 & 0 \\
\hline & 0 & 0 & 0 \\
\hline \multicolumn{2}{|c|}{ Total . . 150} & 150 & 150 \\
\hline
\end{tabular}

noticed that readings above $7.6 \mu$ are rare below the age of 30 , and become common in the older age groups. For instance, in the 80-89 group there were 13 readings above $7.6 \mu$ out of the total of 50 cases.

\section{Discussion}

Our figures show a highly significant upward trend in the halometer readings for each decade after the 30-39 age group. It is not claimed that this trend necessarily applies to the population in general, as the increased values in elderly hospital patients could well be the result of diseases which become increasingly common with age. Neither do we place any weight on the absolute values for
M.C.D. obtained with the Waterfield halometer. This type of measurement was chosen as the only practical means of obtaining a large enough number of figures for the study. Values obtained with this halometer are fairly reproducible; for instance, five different observers each made 100 readings on a set of 10 slides from different patients (500 readings in all), and the coefficient of variation for random error was only $2.2 \%$ (Biggs, personal communication). Inspection of the stained films corresponding to those giving high halometer readings did not show much anisocytosis, and apart from an increase in apparent size the only abnormality was a tendency in some cases to formation of target cells.

Until our findings can be confirmed in a series of persons who are not suffering from any recognizable disease, it would be premature to suggest possible reasons and mechanisms for the rising trend of M.C.D.s with age. The main conclusion to be drawn is one of importance to the practising haematologist, i.e., the red cells of aged patients without evidence of megaloblastic anaemia often show moderate degrees of enlargement which, in the young, would demand thorough investigation to exclude serious disease.

\section{Summary}

The mean red cell diameter was estimated in a series of 450 persons, mostly hospital patients, using a Waterfield halometer. Twenty-five males and 25 females were examined from each decade of age up to 90 years old.

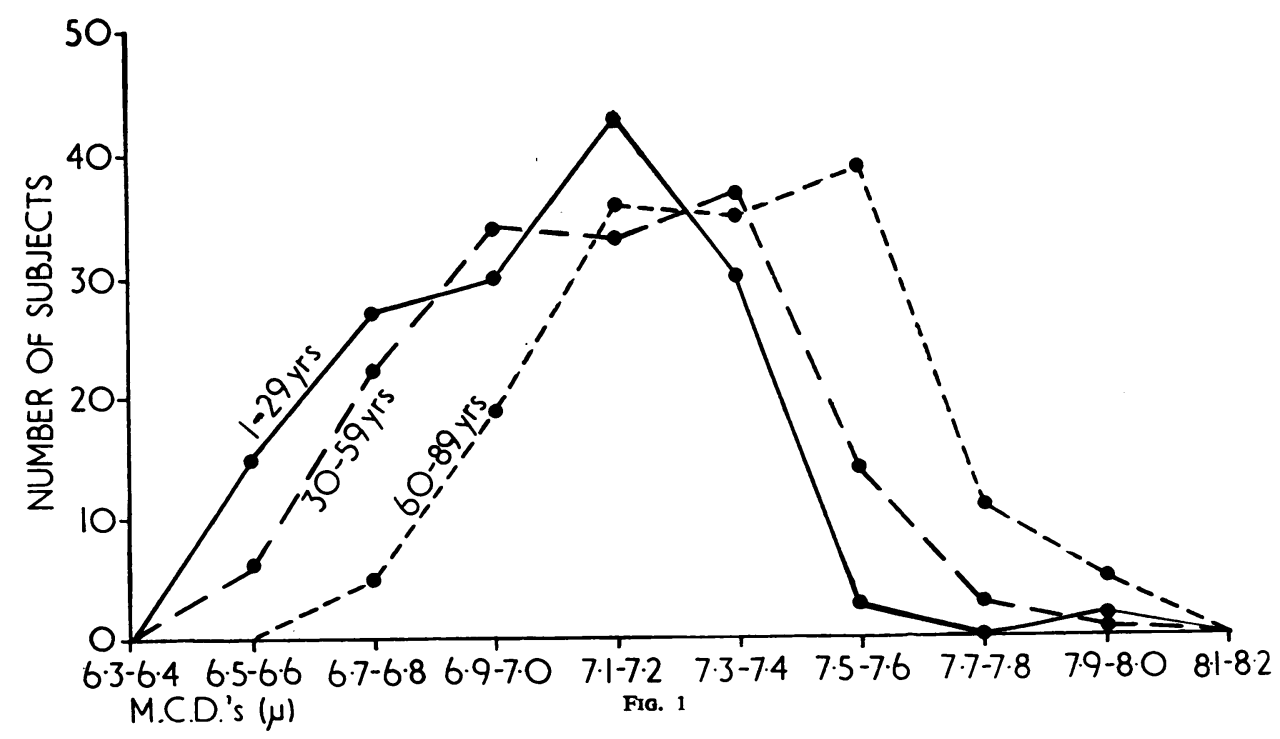


In the first four decades (ages 1-39) the means of the halometer readings remain the same in each decade, but the level for females is slightly above that for males. In the later age groups this possible sex difference disappears, but there is a significant continuous upward trend reaching in the ninth decade a level of $0.37 \mu$ higher than the mean for the age group 1-39.
We are indebted to Dr. A. H. T. Robb-Smith and to Dr. M. M. Pickles for their advice in the preparation of this paper ; also to Dr. N. R. Garden and Dr. R. R. Tilleard-Cole for their help during the investigation. Mr. N. T. J. Bailey kindly gave us his advice concerning the statistics.

REFERENCES

Olbrich, O. (1947). Edinb. med. J., 54, 306.

Price-Jones, C. (1929). J. Path. Bact. 32, 479.

Saragea, T. (1922). C. R. Soc. Biol. (Paris), 86, 312. 